\title{
Aggressive Interactions of Rocky Mountain Elk, Cervus elaphus nelsoni, During the Calving Season Toward Mule Deer, Odocoileus hemionus, in Central Colorado
}

\author{
Robert M. Stephens ${ }^{1}$, A. William Alldredge ${ }^{2}$, And Gregory E. Phillips ${ }^{3}$ \\ ${ }^{1}$ Wyoming Game and Fish Department, 528 South Adams Street, Laramie, Wyoming 82070 USA \\ ${ }^{2} 2518$ Owl Creek Road, Thermopolis, Wyoming 82443 USA \\ ${ }^{3}$ EDM International, Inc., 4001 Automation Way, Fort Collins, Colorado 80525 USA
}

Stephens, Robert M., A. William Alldredge, and Georgy E. Phillips. 2003. Aggressive interactions of Rocky Mountain Elk, Cervus elaphus nelsoni, during the calving season toward Mule Deer, Odocoileus hemionus, in central Colorado. Canadian Field-Naturalist 117(2): 316-317.

We documented four aggressive interactions between Rocky Mountain Elk (Cervus elaphus) and Mule Deer (Odocoileus hemionus) during the Elk calving season of June and July 1995. In one case, we believe a fawn Mule Deer was killed by two cow Elk. In the other three cases, Elk chased Mule Deer away from an area where they were grazing. These incidents are of interest because documentation of such interactions between Elk and Mule Deer is sparse in the scientific literature and because of the concern about declining Mule Deer populations throughout the western United States.

Key Words: Rocky Mountain Elk, Cervus elaphus nelsoni, Mule Deer, Odocoileus hemionus, competition, attack, aggression, interaction.

Aggressive interactions between Rocky Mountain Elk (Cervus elaphus nelsoni) and Mule Deer (Odocoileus hemionus) are not well documented in scientific literature. Elk and Mule Deer appear compatible in most areas, and are frequently observed feeding in close proximity (White 1958; Hirsch 1963). When Elk become concentrated, however, Mule Deer may leave the immediate area. In northern Idaho, Mule Deer use of major salt licks decreased as Elk use increased (Young and Robinette 1939). Waldrip (1977) reported that White-tailed Deer (Odocoileus virginianus) appeared to avoid Elk and were not regularly seen in areas containing dense Elk populations. Telfer and Cairns (1986) reported that groups of cow Elk with calves "mob" solitary Moose (Alces alces), eventually forcing the moose to leave the area. Aggressive behavior by Elk towards deer has been documented in confinement, where a White-tailed Deer immobilized with succinylchlorine chloride collapsed and an Elk (one of seven) rushed over and struck the deer roughly with its front feet (Scanlon 1977). We know of only one other incident where cow Elk were observed striking and killing a fawn Mule Deer (F. Lindzey, personal communication).

We witnessed four aggressive interactions between Elk and Mule Deer. The first was on Meadow Mountain $\left(39^{\circ} 35^{\prime} \mathrm{N}, 106^{\circ} 28 \mathrm{~W}\right)$ in the White River National Forest, Eagle County, Colorado on 22 June 1995. The meadow where the observation occurred was approximately $1.5 \mathrm{~km} \times 0.75 \mathrm{~km}$. Observations were made with $10 \times 40$ binoculars at $200-300 \mathrm{~m}$. The first animal to enter the meadow that evening was a female Mule Deer. She was alert and scanned the meadow for nearly 5 minutes before she began to feed. About 10 minutes later, 10 Elk ( 7 cows, 2 calves and 1 bull) entered the meadow. While the Elk fed they encountered a bedded Mule Deer fawn close to the forest edge. Two cows chased the fawn for approximately $100 \mathrm{~m}$ until it reached the timber and escaped. The Elk returned to the meadow within a few minutes and continued to graze. Near the middle of the meadow they encountered a second bedded fawn. Seven female Elk and two calves chased the fawn for nearly $100 \mathrm{~m}$ for about 10 seconds. The fawn screamed several distress cries while running, and then sought shelter under a small shrub. Two female Elk aggressively stomped on the fawn with their front hooves and the fawn appeared limp after several blows. We inspected the location the following morning, but found only hair from the fawn and a trampled shrub. Thus, we were unable to conclude the fawn's fate, although we believe it was killed. We did not inspect the area until the following morning because our work required repeated observations of Elk in this meadow (Phillips and Alldredge 2000) and our disturbance would have compromised that work.

We observed two other aggressive interactions between Elk and Mule Deer on Meadow Mountain and a third at McCoy Park (3935N, 10632W), also in the White River National Forest in Eagle County, Colorado. On 7 July 1995, 22 Elk (18 cows, 4 calves and 0 bulls) were grazing and using a mineral lick at Meadow Mountain. Two female and one male Mule Deer approached the mineral lick when two Elk chased them away. On 8 July 1995, two female Mule Deer were chased from the same mineral lick by a single Elk (1 of 38 with at least 5 calves in the herd). Lastly, on 23 July 1995, we observed a female, a calf, and two yearling male Elk chase a male Mule Deer from the area they were grazing in McCoy Park. 
As Mule Deer populations throughout much of the West appear to be declining and Elk populations are thought to be increasing, some have speculated that interspecific competition may be a causative factor (Lindzey et al. 1997). Our observations certainly suggest that Elk will displace Mule Deer. Our observations occurred during the calving and calf-rearing season (June and July), suggesting Elk might be particularly aggressive toward other animals they perceive as threats to their offspring during this period.

\section{Acknowledgments}

We are grateful to Vail Associates, Inc. for funding our research on the effects of human disturbance to Elk calf survival. Bill Andree, Colorado Division of Wildlife, provided invaluable assistance throughout the three years of our study.

\section{Literature Cited}

Hirsh, J. B. 1963. Range use, relationship to logging, and food habits of the elk in the Little Belt Mountains, Montana. Master's thesis, Montana State University, Bozeman, Montana. 44 pages.

Lindzey, F. G., W. G. Hepworth, T. A. Mattson, and A. F. Reese. 1997. Potential of competitive interactions between mule deer and elk in the Western United States and Canada: A review. Wyoming Cooperative Fisheries and Wildlife Research Unit, Laramie, Wyoming. 82 pages.

Phillips, G. E., and A. W. Alldredge. 2000. Reproductive success of elk following disturbance by humans during calving season. Journal of Wildlife Management 64: 521-531.

Scanlon, P. F., R. E. Mirarchi, and J. A. Wesson. 1977. Aggression toward immobilized white-tailed deer by other deer and elk. Wildlife Society Bulletin 5: 193-194.

Telfer, E. S., and A. L. Cairns. 1986. Resource use by moose versus sympatric deer, wapiti and bison. Alces 22: 113137.

Waldrip, G. P. 1977. Elk habitat use during calving season with possible effects on white-tailed deer at the Wichita Mountains National Wildlife Refuge. M.S. thesis, Oklahoma State University, Stillwater, Oklahoma. 81 pages.

White, K. L. 1958. Summer range ecology of Rattlesnake Creek mule deer in the spruce-fir zone. Master's thesis, The University of Montana, Missoula, Montana. 95 pages.

Young, V. A., and W. L. Robinette. 1939. Study of the range habits of elk on the Selway Game Preserve. Bulletin 34. University of Idaho, Moscow, Idaho. 47 pages.

Received 11 March 2002

Accepted 17 November 2003 